\title{
Book Review: Bula, A. (2020). Poetry as Throne for Sentimental Reticulation: A Review of Andrew Bula's Turns of Thoughts. Abuja: Old Press
}

Iorwuese Gogo (Corresponding author)

Department of English, Benue State University, Makurdi, Nigeria

Email: gogiorwuese8@gmail.com

Received: 22/06/2021

Accepted: 04/09/2021

Published: 01/11/2021

Volume: 2 Issue: 6

How to cite this paper: Gogo, I. (2021). Poetry as Throne for Sentimental Reticulation: A Review of Andrew Bula's Turns of Thoughts (2020): Abuja, Old Press. Journal of Critical Studies in Language and Literature, 2(6), 33-37

DOI: https://doi.org/10.46809/jcsll.v2i6.114

DOR: https://dorl.net/dor/20.1001.1.27324605.2021.2.6.5.5

This work is licensed under the Creative Commons Attribution International License (CC BY 4.0). http://creativecommons.org/licenses/by/4.0/

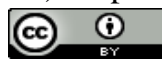

This review article is a critical inspection of Andrew Bula's collection of poems, Turns of Thoughts (2020). As such, critical searchlights are thrown on poems as "Turns of Thoughts", "Who Knows", "Keeping Vigil", "Love to Love", "Wall Gecko", "Far Out to the Woods", "King on Fours in the Wilds", "Trekking Home on a Windy Night", 'Presence and Space", "Neighbour, Let’s Hate Hatred", "Much Minuses \& Little Pluses", "To Illumine our Rich, Fine World". In investigating these pieces, the aim really is to uncover the message and artistry of Bula's poetry. There are, of course, other pieces in the anthology that are simply mentioned in this review, without depth analyses. In such circumstances, the tendency is to liken them to other piece(s) or, quite simply, to take a cursory view of them. And then there is a showcasing of dominant literary devices as found in the poems as Rhetorical Questions, Paradox, Simile, Metaphor, Personification, Allusion, and Code Mixing. In the end, it is made out that Bula's poetry is one of emotional elation and it reveals high moral awareness of, and gratitude to, important members of the public who have positively impacted society. Likewise, it is discovered that the poems also explore nature, love, and philosophical themes, while employing literary devices such as have already been mentioned.

Turns of Thoughts (2020) is Andrew Bula's debut collection of poems. A burgeoning talent in the sphere of contemporary African poetry, Bula is a multitalented writer and scholar of literature whose creative talents and interests range from poetry, prose-fiction, and drama. As an alumnus of Benue State University, Makurdi, Bula is a proud product of Writers League (an association for undergraduate students' writers in the Department of English) who has shone to international level with his creative outputs and was, in fact, the president of the students' body of writers over a decade ago.

Akwanya (2021) in an interview which he grants Bula (2021) speaks of poets who have what is generally tagged moments of inspiration and produce poems while the moments endure (p. 27). This view of Akwanya's informs the art for art's sake school of thought which assumes that art is innate and, as such, artists are born and that art emanates from certain triggers of the individual artist. This perspective can, therefore, be linked with Bula's collection of poems, Turns of Thoughts. Turns of Thoughts (Poems) is a collection of thirty-one short poems which are prompted by emotional experiences, enveloped in philosophical contemplations. In it, the poet displays his high level of intuition and zeal for thoughtfulness. The poems are carefully measured in witty language and fascinating imagery. Thematically, they are preoccupied with moral consciousness, love and intimate relationship with its complexities, nature, tributes to African literary and political icons, philosophy, and the enheartening of Nigerians.

The poem, "Turns of Thoughts", which is the work's titular poem, is deeply philosophical as it invokes Plato's view on morality, that what is good is anything that is in between two extremes. The poem, therefore, cautions against sticking to one 
thing narrowly as it encourages modesty in order for one not to lose out achieving in life. This is expressed as follows:

Better then not to cling too much to one side

Barren of wisdom except hesitation, as of a snail's horns

Though not to a side that hurts on large a scale.

For the middle way is better a way to safety

Though in the end safety itself isn't safe a zone (p.1)

These lines can be considered philosophical as they are woven in deep thoughts, revealing the puzzles in life. Too, the poem decries the encouragement and celebration of people who are achieving success in society via dishonest means as against those who believe in mounting the social and financial rung through appropriate means. This can be witnessed in these lines:

Though, merely, but pondered by what measure life gives

Tidings to those with dishonest means but not to worthy those

Who amidst harrowing cracks, yet with quiet strength struggle

Is it the wily ways of the world are better treaded? (p.1)

The poem, "Who knows...?" is as well philosophical, because it deliberates the paradoxicality of life and society. Hence: "If the beginning is the end/ And the end the beginning "Who knows .../ If the crown is the cap/ And the cap crown" (p.29).

The theme of love and intimate relationship with its attendant complexities is deeply expressed in the collection of poems where the poet's persona lays bare his emotions in yearning for love and lamenting the conundrum which love and intimate relationships pose to him. In this case, the poet's persona recounts his sweet and bitter experiences with love as it can be emotionally uplifting, and yet, dispiriting. Thus, the poems which deal with the subject matter of love and intimate relationship with its complexities in the collection of poems are, "Keeping Vigil", "Wall Gecko", "A Message to Shidoo", "Love to love", "To Kpadoo, with Love" and "Solve Me this Puzzle". In the poem, "Keeping Vigil", the poet's persona reaches for love and companionship to fulfill his emotional needs from his absent partner. He laments bitterly the early morning hormonal charges of the human body that trigger wild sexual fantasies which without a partner for companion induces crazy feelings. This is revealed thus:

$$
\begin{gathered}
\text { Tonight I shall sleep alone } \\
\text { No - with jealousy beside me } \\
\text { My heart sighs at each growth of night } \\
\text { And daylight is long coming } \\
\text { My love, how unfair } \\
\text { O! How unfair } \\
\text { For how long shall we wait? }
\end{gathered}
$$
How long?

Tonight I feel cold, so cold like the winds of harmattan

Though the blinds are fixed

I'm frozen with foxy love

And out there

I eavesdrop the winds rant and rave

Is any too cheated? (p.3)

Therefore, despite the poet's persona's disappointment with his absent lover, he resolves to show her love upon her return:

At dawn, upon your return

I shall see you through my tears and utter:

I still love you (p.4)

The poem, "Love to Love" contemplates the concept of love as a human virtue and suggests that love can be blissful to human existence, if truthfully shared. This is marshalled in these lines:

Learn then the ways of love

The naked type, devoid of hate

The naked type, devoid of empty fear

The pure type, without a shred of schemes.

And though which way to bliss be bad

Unkempt \& dirty as a thousand year's soot

Wait, wait for love and keep faith

For love is love, and will in time bless (p.26)

These lines inform that when society imbibes the true principles of love, which is humane, without gimmicks or pretence, the world will be devoid of misery but happiness. In "Wall Gecko" and "Solve Me this Puzzle", the poet's persona laments his own long suffering of a lover's wiles and underhandedness. This finds expression, to quote just from "Wall Gecko", in the following:

She's baked fine and fair from clay. 
She's mine - and I hers?

Not a deed of hers can assure.

Though I offer all of my all

For all her cheek and cunning!

For all her charmed innocent harm

Yes, for all her conditioned mentality

As I metal, she human and woman (p.6)

Nature's presence is felt in the poetry as the resourcefulness and attractiveness of the forest is represented in the poem, "Far Out to the Woods". The "woods" here indicates a forest and its surroundings where one can fetch fodder to feed domestic animals kept for business or for consumption or other needs. As such, while one wonders around a forest one can be exposed and attracted to an abundance of resources that serve society. This is captured in the entirety of the poem:

Far out to the woods

Hear! The axing of trees,

To where must be fodder.

Long without have been the goats

Besides their cuds to chew.

Now here, fetch chop-chop, fetch

Cut from among chaste foliage,

Not of blighted mango leaves,

That we might dash back in time.

For long without have been the goats,

Besides their cuds to chew,

And the timekeeper bird has warned

Of our puny haste, like tortoise's

Tempting though the woods are

What with fat rodents about,

Doves greedy with easy pickings,

And the cool of dense forest canopies (p.2)

Thus, in the thicket, one has the luxury to choose the freshest of greens or fruits to fetch for food or for feeding of livestock. The "fat rodents" and "easy pickings" speak to the richness of the forest to the advantage of humans and doves who feed on them respectively while "the cool of dense forest canopies" attests to its lulling and alluring attributes. The poem, "King on Fours in the Wilds" venerates the mightiness of the lion, a carnivore in the wild, as it dominates the wild taking down huge animals for food. This is revealed as follows:

O Lion! King on fours in the wilds

For ages and ages gone by, and greying

Tales \& praises of your sight linger on

As are the marvels of your deeds: ...

I dress you in the robes of your majesty (p.11)

Through these lines, the poet's persona expresses awe at the strength and courage of the lion that have made it fearful and exalted since time immemorial. The poet's persona also salutes the lion for its dreaded but inspiring appearance and existence. In the poem, "Trekking Home on a Windy Night" the poet's persona laments the impact of hurling winds on him on his way home. He thus begs for calm from the wind in order for him to find his way home:

Peace, peace, howling night force

Your sweeping tongue's rage - who can bear?

So peace, wind force, peace, and grant weak knees path

To inch home like one-legged cricket (p.25)

Another interesting aspect of the poetry is its unique tributes to mothers and African literary and political icons. Therefore, the poem, "Immortality" pays tribute to mothers. "Sweet Continent Man of Mine" is a tribute to Nelson Mandela, a black South African political leader who fought the apartheid regime in South Africa to the finish when the black majority took over leadership of the country in accordance with proper democratic principles. "You are My Retinas" is a tribute to Chinua Achebe, a global Nigerian novelist and literary icon. "You are a Soldier" venerates Professor David Ker, a scholar, literary critic, and an academic of international repute, for his strides in his academic career, having served as Vice Chancellor in two different universities in Nigeria - Benue State University, Makurdi, and Veritas University, Abuja. "Notes From Guitar Strings" is a tribute to Professor Ossie Onuora Enekwe while "Vessel of Honour" pays tribute to Wole Soyinka, a Nigerian playwright of global repute and winner of the Nobel Prize for literature in 1986. These tributes to mothers and 
African literary and political idols show the poet's gratitude and honour to them for their influence in his life, career, and society in general.

More to the point, poems such as: "Presence \& Space" and "Neighbour, Let's Hate Hatred" show the moral consciousness of the poet as, through them, he calls on human beings to love one another and build candid relationships while shunning envy and jealousy that are rather destructive. These lines in "Presence \& space" do the admonishing:

When then you meet presence, the human I mean,

Treat with regard - the best of the spirit in place!

And be sure to grant in fair play needed space.

Thus sweeping off harm as would a broom dirt. (p.17)

"Presence" in the poem indicates human beings while "space" means the environment. The idea is that when there is equity and justice in society and human beings are supporting one another, peace and progress would reign which is ideal and progressive. In "Neighbour, Let's Hate Hatred", the message comes out thus:

Need we be 'planted' to yield tears?

Neighbour, let's in time bind up this gash

And thus retrieve our hearts' health

If I own not the patch, I'll let slide the case

So when a kind morning offers me a smile

And I would that you share some with me

Do not farm freckles upon your crown

For all can't be ours, though desires tauten

Hurling curses at fate and fortunate men.

If, then, my verse's utterances utter wisdom

Neighbour, let's hate hatred whose hate loves not. (p 33)

In the above lines, the poet's persona charges people to make peace and friendship with their fellows in communities and work places for the purpose of unity and prosperity against quarrels which are ruinous. Similarly, in poems like "Much Minuses \& Little Pluses" and "To Illumine our Rich, Fine World", the poet laments the slow growth of Nigeria and her people but urges his compatriots never to give up but continue to make credible efforts in uplifting the nation. In "Much Minuses \& Little Pluses", these lines are revealing of the foregoing:

Brother, O! Brother, the matter is same at home

This home with colours green, white, green

This home seen as a hearth with merely three stones!

Yet home shared by all homesteaders -

Themselves with much minuses, little pluses: (p.28)

This is a plea by the poet's persona to his Nigerian compatriots to remain steadfast so as to ensure growth for the country despite the fact that it has been marred by tribalism, nepotism, regionalism and bad leadership.

In "To Illumine our Rich, Fine World", the idea is seen in these lines: ... men \& women of my kin

Hold high your heads and never in fear let them lower,

Nor in naivety fail to arm and sheath well to the teeth

People of my kin, be thus as wise as the ancient North star,

Bearing, to wit, the torch to illumine our rich, fine world (p.31)

Here, too, the poet's persona summons his compatriots to continue to be vanguards of their nation albeit the corrupt nature of the leaders.

As pertains to technique, the collection of poems is interlaced with figurative and poetic devices that have proven its artistic quality. Code mixing and imagery are also deployed in the work, thus making it colourful and insightful. Therefore, the dominant literary devices found in the poems are:

Rhetorical Questions: "is any too cheated?" (p.3), "is it the wily ways of the world are better treaded?" (p.1), "For how long shall we wait?" (p.3), "She's mine - and I hers?" (p.6).

Paradox: "... safety itself isn't safe a zone" (p.1), "Of our punny haste, like tortoise's (p.2), "Who knows.../ If death is life/ And life death" (p.30)

Simile: "That like a snail, your shell does descend" (p.5), "Lest at you more evil charges, like a Roman battle chariot" (p.31), "Like a thread through a fabric" (p.27).

Metaphor: "My lady is a wall gecko!" (p.6)

Personification: "And let thoughts grant me leave" (p.8), "I doff my hat and kneel in homage to memories" (p.20), "...let's hate hatred whose hate loves not." (p33)

Allusion: "Or Lazarus whose pockets hold nothing" (p.28), "...like a Roman battle chariot" (p.31)

Code Mixing: "The me kpe a o, me kpe a o notes of a songbird" (p.3), "The Organden tremble as he treaded (p.13), "Sir, ungu pinen or shinii?" (p.13), "For want of gbodi - and no wherewithal" (p.15), "Ir-kwase-o when I flip through the pages" (p.27). This, undoubtedly, is code mixing of English and Tiv languages, and it enriches the poems with local colourations. 
Bula's Turns of Thoughts is poetry of emotional bliss and it demonstrates a high sense of moral consciousness, gratitude and reverence to teachers, African literary and political idols, mothers and elders for their impact in shaping society for the better. The poetry also treats nature and love, which positively builds society when properly handled, reflecting its power and enigma. Moreover, Bula's poetry can also be considered a philosophical labour for its engagement with social phenomena while its use of figurative devices, imagery, and clever code mixing establish its artistic excellence. In all, the collection of poems makes good reading, especially for lovers of good poetry.

\section{References}

Bula, A (2021). Literary Musings and Critical Mediations: Interview with Rev. Fr Professor Amechi N. Akwanya. Journal of Practical Studies in Education 2, 5, pp. 26-31

Bula, A (2020). Turns of Thoughts. Abuja: Old Press. 